$\left[\begin{array}{l}\text { Jpn. J. Hosp. Pharm. } \\ \text { 報 } \\ \text { 19(5) 告 }\end{array}\right]$

\title{
新しい在庫管理システムの構築
}

\author{
池窪弘務, 芦田真弓, 畑 博明 \\ 大阪厚生年金病院薬剤部门
}

\section{Development of a New Drug Inventory Control System}

\author{
Hiromu IKekubo, Mayumi Asida, Hiroaki hata \\ Department of Pharmacy, Osaka Kosei Nenkin Hospital $\dagger$
}

( Received April 8, 1993 Accepted July 21, 1993 )

\begin{abstract}
Introducing a barcode system enables systematic inventory control in drug dispensaries and pharmacies. Additionally, the system efficiently reduces the number of personnel and rationalizes the inventory at the same time. In developing this new inventory control system employing barcodes using a microcomputer, we have greatly facilitated rationalizing pharmaceutical storeroom management.
\end{abstract}

Keywords - inventory control; prescription department; barcode system; storeroom

\section{は じめに}

従来, 病院での薬品在庫管理は, 薬品倉庫での 品質管理, 経済管理, 供給管理等を主としてきた が，これを調剤室を中心とする消費部署で在庫管 理が十分行えるなら, 薬品倉庫の役割も变化し, 従来の倉庫業務を大幅に合理化できる可能性があ る. 当院, 薬剤部補給室では, 10年来, パーソナル コンピューターで独自のプログラムを組み, 薬品 の在庫管理を行ってきたが，バーコードシステム を在庫管理システムに組み込むことにより，とも すれば経験や勘に頼りがちだった調剤室での在庫 管理を統計的にとらえることができると考えた。 そこで今回バーコードを用いた新しい在庫管理シ ステムを構築すると共に, バーコードリーダーを 用いた薬品倉庫業務 (入庫, 出庫, 伝票のキーボ 一ド入力等)を大幅に合理化したので報告する.

$\dagger$ 大阪市福島区福島 4-2-78; 4-2-78, Fukushima, Fukushima-ku, Osaka-shi, Osaka, 553 Japan

\section{1. システムの特徵}

バーコードを利用した在庫管理システムについ て，種々の報告 ${ }^{1-4)}$ があるが，薬品の在庫管理特 性（新規の購入薬品, 品切れの可能性の高い薬品 の安全在庫量の設定, デッドストックの注意等） や在庫管理パラメーター（救急薬, 在庫輸液, 高 価薬, 希用薬等) を請求用のバーコードラベルに 任意にプリントアウトでき, 請求業務を支援する システムの報告はない. 我々は, バーコードに上 記管理パラメーターを組み込み，一貫した管理シ ステムを構筑すると共に薬品在庫を持たない方法 を検討した．ただし，救急薬品に関しては緊急時 対応に備え, 一部倉庫に在庫を置き万全を期し た. 本システムにより, 在庫輸液 (約10品目) 以 外は, バーコードによる請求量が問屋への発注量 になり, 臨時発注数, 急配数の減少により，1日 1 回のスムーズな流通体制が確立された. また本システムは, 伝票のキーボードからの入 
力を簡便化し，オペレーターの業務を大幅に減

じ, 従来の 1 日約 1 時間のキーボード入力が約 10 分に減少した.

2. システムの構成

〈ハードウェア〉

パーソナルコンピューター

PC-9801DA（日本電気）

ユーザーズメモリ1. $6 \mathrm{MB}$

バーコードリーダー

PI-90

通信ユニット

PI-90PH

バーコードイメージジェネレーター

PC-Big/s (Welcat)

転送ユーテリティ

BHT-BASIC Ver 3.0

インターフェイス

RS-232C

プリンター

BJ330J(Canon)

ハードディスク＆ストリーマー

TEAC DS-41 \& STREMER $40 \mathrm{MB}$ (Teac)

〈ソフトウェア〉
OS

MS-DOS Ver 3.3C

プログラム言語

N88BASIC Ver 6.0

バックアップ

毎日業務終了後 CT-600N

(DATACASSETTE) に矅日別に

バックアップ

\section{3. プログラムの概要}

バーコードシステムの導入に伴い, 新しく作成 した主なプログラムは表 1 の通りである.なお， コンパイラは使用していない。

\section{4. システムの概略}

図1亿示すように, 調剤室で, 請求品目をバー コードリーダーで読み取り, 補給室で, これを通 信ユニットにセットし, RS232C インターフェイ スを介して, ハードディスクに発注量（二調剤室 からの請求量）として記録する.

記録されたデータは問屋別に発注書としてプリ ントアウトし,ファクシミリで発注する. 同時に 請求者が請求品目の確認が出来やすいように, ハ ーコードリーダーで読み取った順番に, 請求品目 をプリントアウトし, 請求者に返す.

翌日, 薬品倉庫で, 図 2 に示すように, 発注書

表 1. プログラムの概用

\begin{tabular}{|c|c|c|}
\hline プログラム & 内 & $\# 17^{*}\left(n^{*}\right.$ 仆) \\
\hline 納品伝票入力 & $\begin{array}{l}\text { 納品数=庫出数として同時に在庫 } \\
\text { マター書き込む。 }\end{array}$ & 30,232 \\
\hline $\begin{array}{l}\text { 定期納品伝票の } \\
\text { 自動入力 }\end{array}$ & $\begin{array}{l}\text { 未納品入力後、発注数=納品数、書 } \\
\text { 庫出数として、在庫マスタ納品は、納品、伝票入 } \\
\text { き込む。納品として記録さ } \\
\text { 力があるまです。 } \\
\text { れる。 }\end{array}$ & 15,439 \\
\hline $\begin{array}{l}\text { バーコードによ } \\
\text { る請求量の入力 }\end{array}$ & $\begin{array}{l}\text { 品目ごとのバーコード入力数を発 } \\
\text { 注数として、在庫マスターに書き } \\
\text { 込む。 }\end{array}$ & 14,484 \\
\hline 調剤室在庫管理 & 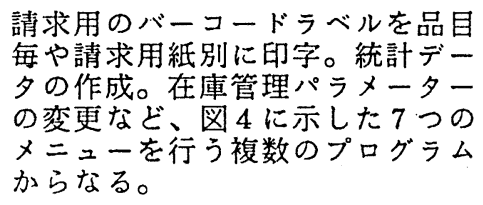 & 略 \\
\hline
\end{tabular}



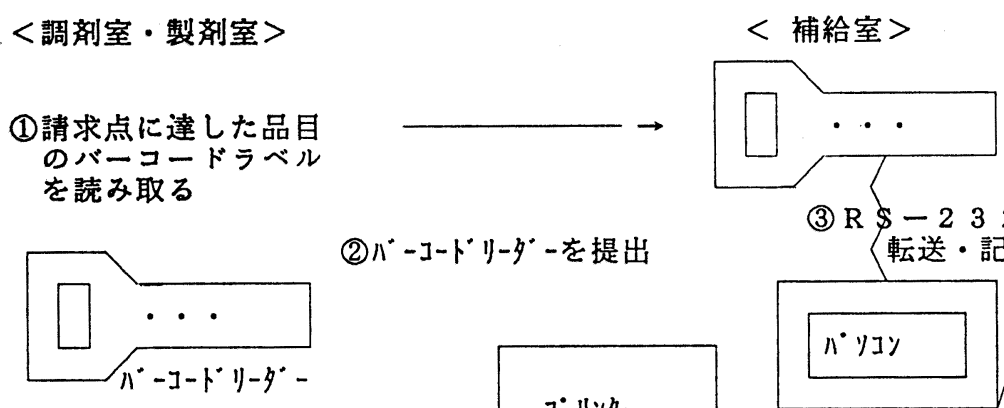

(2)バーコードリーダーを提出

(3) $\mathrm{R} \$-232 \mathrm{C}$

転送・記録

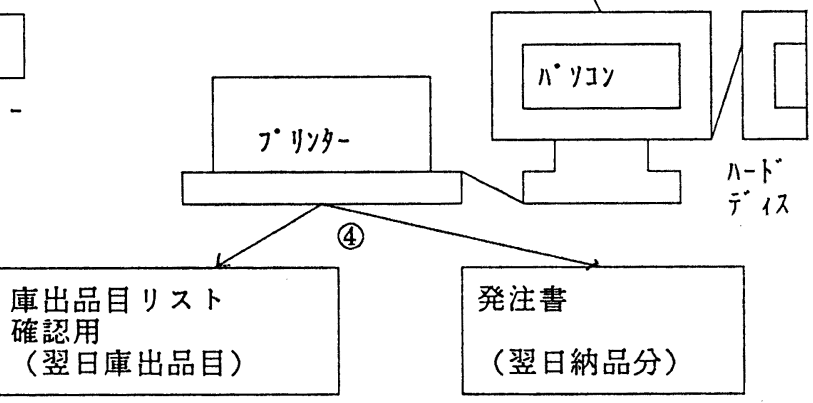

ペーコードリーダーで読み

取った順番に打出し

ファクシミリーで

各請求者に渡す。

問屋に発注。

図 1. 調剤室からの請求と問屋への発注

<薬品倉庫 $>$

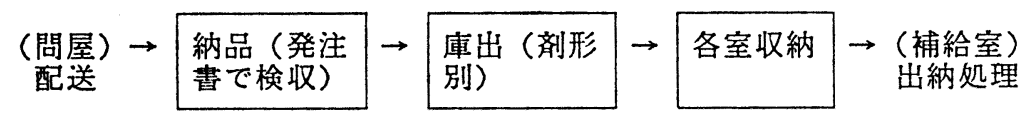

因2. 納品 - 庫出

と納品伝票を照合した後, 補給室担当の 2 人でフ フクシミリ送信した発注書（単位，メーカー名を 併記）により納品を行う. 発注書による検収は, 問屋の伝票による検収より単位等の納品間違いを 防ぐことができる.

納品後, 倉庫在庫品目以外は, 各室に収納しゃ すいように，注射，錠剂等の担当者別に払い出 す.

\section{5. システムの檴成}

適正な在庫管理を行うためには，品目の特性 (救急性, 品質, 経済性等), 作業能率 (購入回 数, ストック場所）を十分考兄, かつ変動する使 用量にも対応できるシステムが必要である.

具体的には，因 3 のように 3 力月毎に新しい消 費データと品目の特性および作業能率を考慮し,
基準を逸脱した品目および特殊品目を再検討し， 在庫管理パラメーター（次項で述べる薬品データ ファイルに記録された請求点, 発注量, こま数等) を更新する. 更新したパラメーターにより, 変更 品目のバーコードラベル（Cの項で述べる請求時 バーコードリーダーにより読取るラベル）も更新 し, 流動的な在庫管理に対応するシステムを構築 した.

以下, システムのためのデータ管理およびオペ レーション, バーュードシステム, 在庫管理パラ メーターの設定について述べる.

A. 薬品のデータファイル

調剂室在庫管理の資料となるのは, 薬品毎に作 成された薬品のデータファイルである.

従来の在庫管理データに連動（同一レコード） 


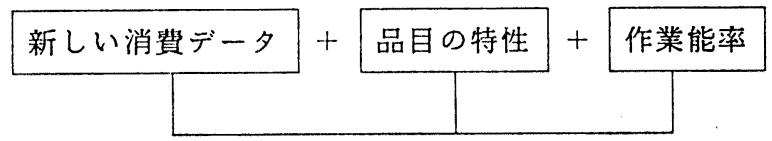

資料検討

薬品の出納管理パラメーターの更新

$\downarrow$

バーコードラベルの更新

（更新されたパラメーターに基づく在庫管理）

図3. システムの構成

して，品目ごとに新しいデータとして下記の項目 で作成した. パラメーターファイルの形式は、レ コード長 256 バイトのランダムファイルである.

1 レコード(256バイト)に記録される内容, フィ

ールド名等を表 2 に示す.

システムの初期値は, 3 カ月間の実績から算出 した 1 カ月の平均使用量を, 包装単位の $1 \sim 8$ の 整数倍で除し, 商が整数に最も近い值を発注回数 として自動算出した.この例では, 購入額の上位 品目なので, 月発注回数は, 最大值の 8 を設定し ている. 請求点は $4 \sim 7$ 日相当量とし, 端数を切
り上げ（150錠は200錠とする．実務上意味のない 桁の数字を切り上げた）自動算出した值を初期値 とし理論上品切れの起こらない量と考えた。こま 数は, 調剂室の最大保有量で, システム導入前の 状況を調査し, 逸脱する品目は発注量, 発注回数 も含めて再検討した. 特殊要因は, 上記のパラメ ーターで管理できない品目で, 請求バーュードラ ベルに印字し, 請求者の注意を促すためのパラメ ーターである.な拉システムの初期值の算出方法 は深井ら 5 の報告を参考とした。

その他, パラメーターの設定は, 過去のデータ

表 2. 薬品のデータファイル

\begin{tabular}{|l|l|l|}
\hline \multicolumn{1}{|c|}{ フィールド名 } & \multicolumn{1}{|c|}{ 記録内容 (例) } & 備 \\
\hline レコード番号 & 562 & 在庫管理データと同じ \\
\hline 薬品名 & アリナミン F 錠 & 在庫管理データを使用 \\
\hline 包装 & 1000 & 1 包装単位 \\
\hline 月使用量 & 21000 & 1 カ月平均 \\
\hline 一回発注量 & 3 & \\
\hline 月発注回数 & 8 & 8 回以内に設定 \\
\hline 請求点 & 5000 (7 日分) & $4 \sim 7$ 日分に設定 \\
\hline 特殊要因 & 二析の数字で記録 & 77 は希用etc \\
\hline こま数 & 8000 & $\begin{array}{l}\text { 請求点+発注量 } \\
\text { 最大保有量 } \\
\text { 置き場所の容量 }\end{array}$ \\
\hline
\end{tabular}


より試算を行い, 在庫金額の推定および, 1 日の 購入数が 150 点以内になるように調整した.

（例） アリナミン F 錠のレコード（表 2)

B. 調剤室在庫管理のメニューテーブル

図 4 のメニューは階層式で, メインメニューか ら下位メニューへと選択することにより,データ の修正, 統計資料の作成, 薬品リストの印字, ハ ーコードラベルの作成が，簡単にできる。

1 番のメニューにより, 表 1 の月使用量のデー ターを更新する. 月 8 回以内の発注回数で 1 回発 注量を変更する必要のない品目は, 自動的に発注 回数を更新し，それ以外の逸脱する在庫管理パラ メーターの品目を要検討品目として, プリントア ウトする.

$2,3,4,7$ 番は, 種々の様式でバーコード リストを打ち出すメニューである.

5 は現在庫管理パラメーターで在庫管理を行っ た場合の, 発注回数, 調剂室の最低在庫金額, 最 高在庫金額を試算するメニューである.

6 は在庫管理パラメーターを変更するメニュー である.
C. バーュードラベルの作成

本システムの中心となるのは, バーュードラベ ルによる請求である. バーコードラベルに, 請求 点, 請求量を印字し, 誰にでも簡単に請求業務や バーコード作成が出来るシステムを目指した。ま た, 請求点, 請求量, その他の因子（救急薬, デ ッドストック対策, 経済管理等) に統計的なデー タをバーコードラベルに反映できるようにした.

当院の在庫管理システムでは, 各薬品のデータ は図 5 のように 1 レコード 256 バイトに 1 品目の データを割り当てている.

医薬品請求用のバーコード番号は, 商品につい ているバーコードからも請求できるように, JAN コードを採用した，JAN コードのない品目は, 在庫管理のレコード番号をバーコード番号とし た。

バーュードの印字に, バーコードイメージジェ ネレーター PC-BIG/s をパーソナルコンピュー ターとプリンターの間に接続し, 自作の BASIC のプログラムに印字コマンドを組み込むことによ り, 図 6 に示す, 薬品名やその他のデーターとバ

調剤室在庫管理プログラム

MEN U

調剂室平均庫出数の更新と発注要因の変更・・・1 1

請求用紙の作成・変更・バーコード印字 …2

請求用紙別発注要因のリスト・・・・・・・ 3

バーュード表・・・・・・・・・・・・4

発注回数、最低在庫、最高在庫を試算・.... 5

発注要因の変更・........... 6

バーコードラベルの印字（カラー）・・・・・7

おわり ............... 8

$\mathrm{No}=$

困 4. 調剂室在庫管理メニュー画面 


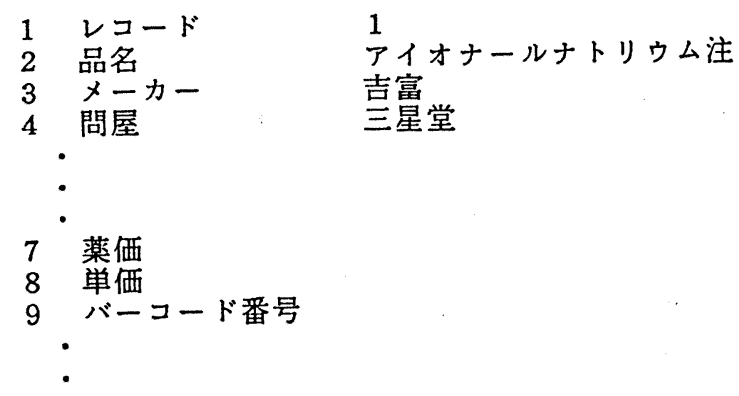

図 5. 在庫管理ファイル

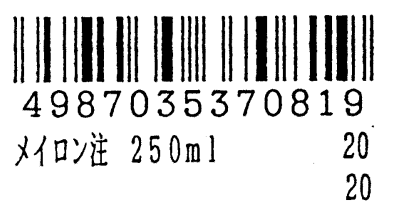

図 6. 請求バーュード

ーュードを印字することが出来る.

図 7 のバーコード一覧表はストック場所別に作 成し, 請求者は請求品目の曜日にマークし, 最後 に一括してバーコードに読み取らせるように工夫 されたものである：請求品目が末収納でも，前日 の請求の有無が分かり，1枚のリストで 1 週間使 用できる. 請求場所の担当者のアイディアを具体 化したものである.

その他, 図 8 のように薬品棚の薬品名表示にハ ーコードを印字することもできる。
D.バーュードによる請求システム

請求者は, 薬品ラベルから, バーュード読取機 で読み取る事により, 請求業務を行ら. 商品に付 いているバーコードによっても請求ができる. 1 回読み取れば， 1 回請求量が，2回読み取れば 2 回分の請求量が, 読み取る回数により, 1 回請求 量の整数倍が請求される.また, 請求ラベルに は, 図 9 に示す例のよらに品目の特性が印字され ている.

またこれらの在庫管理要因の設定について は, Eで述べる。

E．適正な在庫管理をするための要因

適正在庫を含めた薬品管理の要点は以下のよう にまとめられる。

○品質管理

○救急薬品の管理

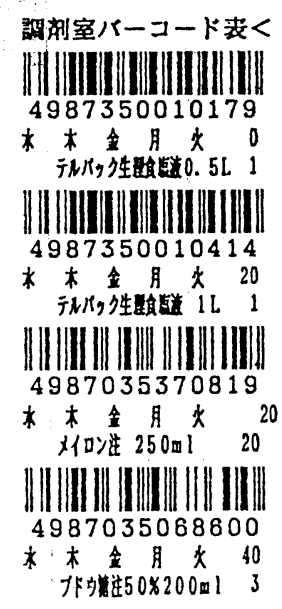

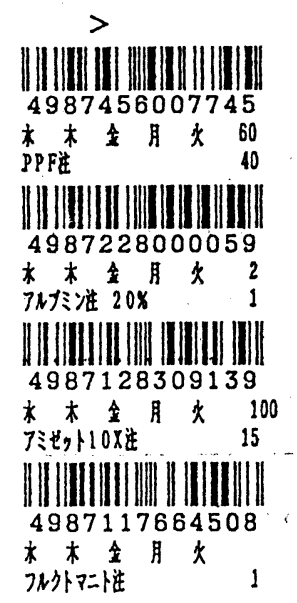

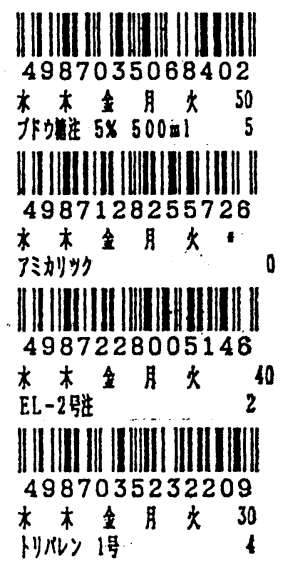

因 7. 注射薬請求バーコード表 


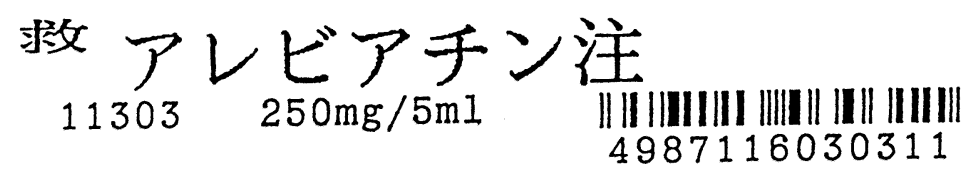

因 8. バーコードラベルの応用

例 1 消費が平均している品目

|| || |||||||||| ||||||| | ||||||||||

4987123063494

Pリ犬ミン

例 2 新規購入

5000 -一請求点

3 -一請求量

|| || |||| || ||| |||| ||| || || || ||

4987081140336

クレメジンカプ㸪

*ー一新規品目である事を示す。

例 3 希用品目

- 一請求量は暫定。

|| || ||||| || || |||||||||||| ||||||

4987087000825

ケวリy

一一請求点は印字しない。

——空白が希用薬を示す。請求量 1 包装

単位

困 9. 請求バーコードラベル

○デッドストック対策

○経済的な管理 (A B C 分析の $\mathrm{A}$ 品目の重点管 理)

○人手を取らないシステム（問屋も含めた業務 の合理化, コンピューターの利用)

○確実な検収（単位違いなどのチェック）

○変動する消費量に対応できるシステムである こと.

○経験や能力に関係なしに誰にでも出来るシス テムであること。

○責任体制が明確なシステム

○当事者以外のチェックが入るシステム

以上の点を考慮し, 在庫管理パラメーターを設 定した。

まず，救急薬品の品切を起こさないことを最優 先とした。また，使用量にむらがあり，月平均使 用量のデータからは品切れの可能性のある品目は 請求点をかさ上げし特別管理品目とし; デッドス トックに注意しなければならない品目は希用薬と
した.

その他, 経済的な管理の必要な A B C 分析の A 品目を高価薬とし，問屋の配送負担と調剤室の在 庫スペースを考慮して, 輸液の一部と大型品目を 倉庫在庫品目とした。

図10のフローチャートにしたがって，薬品毎に 請求点, 請求書, 特性を定め, 薬品のパラメータ ーファイルに記録し, 請求時必要なパラメーター は，バーコードラベルに印字した。

以上のフローチャートにより設定した項目をま とめると表 3 になる.

項目の分布と 1 力月発注回数（倍数発注は倍数 回として計算）を表 4 に示す.

次に, 旧システムと新システムの業務量の比較. を表 5 に示す.

旧システムは, 週一回の定期納品により薬品倉 庫に入庫し, 各室の請求伝票により庫出する。発 注様式は, 発注点を割った品目を一括して発注す るシステムをとっていた。新システムでは，毎日 

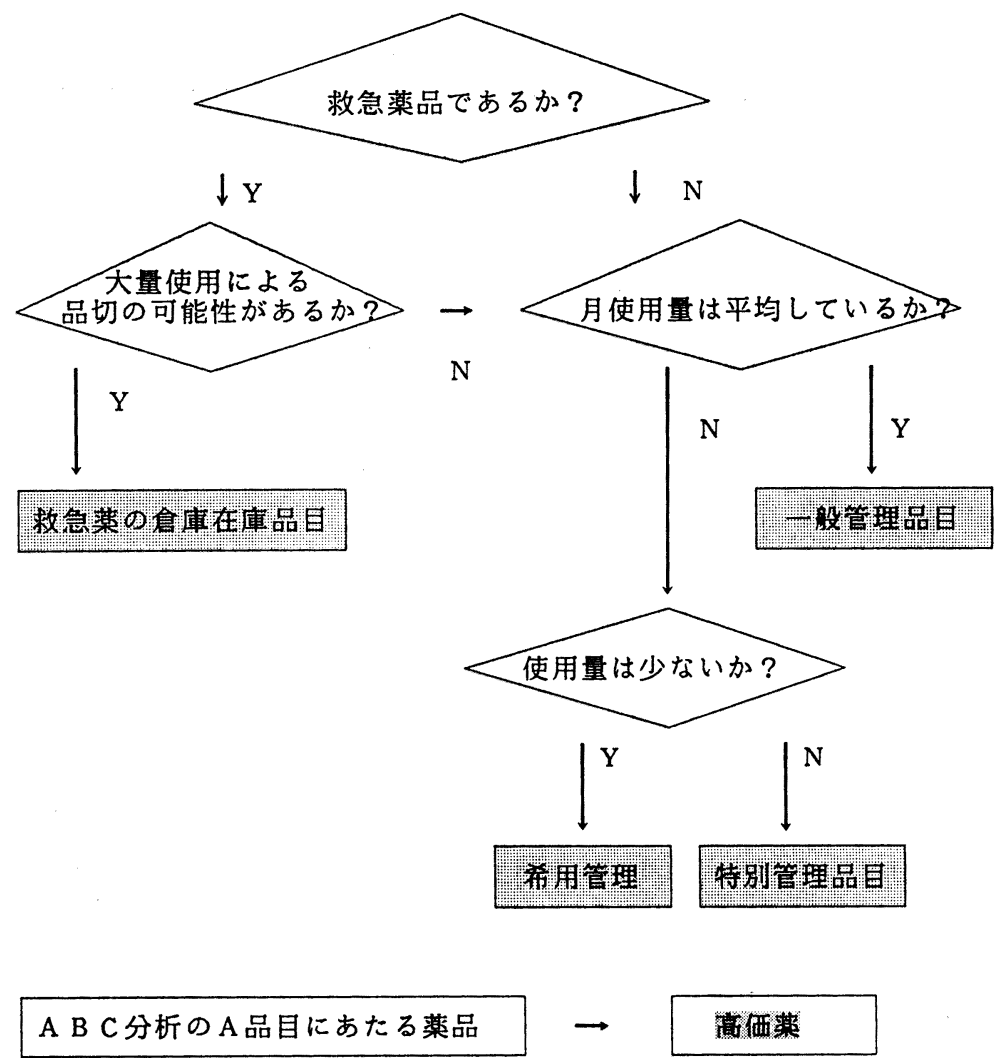

大量消費の輸液、ハップ剂等の大型品目 $\rightarrow \quad$ 旡庫在庫品目

図 10. 在庫管理パラメーター設定のフローチャート

のバーュードによる請求を発注数とし, 納品後, 即庫出するシステムをとった.

新システムでは定期納品数が約 2 倍になった が，入庫の手間がいらず，旧システムの庫出も含 さ業務が約 2 倍の時間で可能になった.

また，伝票入力の自動化により，すべての伝票 をキーボード入力していた旧システムに比べ業務 量が激減した。

新システムのデーターは平成 5 年 5 月との比較 だが，臨時発注は約10分の 1 になった. 旧システ ムでは，月末に倉庫在庫を圧縮していた因子と， 週 1 回の発注のため品切れが生じたためである. 新システムにより, 問屋配送が 1 日 1 回ですみ, 旧システムのような月末業務の偏りがなく，急配 が殆どない等の問屋側のメリットも生じた。
その他, 請求業務に要する時間については, 比 較するデーターを持ち合わせていないが，システ 么の移行時は操作や手順の不慣れのため, 若干の 延長がみられたがバーュード用紙の工夫などによ り数カ月で解消した。

以上業務量は, 旧システムの約 3 分の 2 になっ た.

F．在庫管理パラメーターの更新

3 カ月毎に使用量の変化に対応するため, 下記 の品目について, 在庫管理要因の検討を行う.

$\bigcirc 3$ 力月納入のない品目

$\bigcirc$ 力月 9 回以上の購入品目

請求点 4 日以内の品目

○高価薬

前回新規購入品目 
表 3. 在庫管理パラメーター

\begin{tabular}{|c|c|c|}
\hline 項目 & 目的 & 内容 \\
\hline 一般品目 & - & $\begin{array}{l}\text { 安全在庫 (請求点) は } 4 \sim 7 \text { 日分 } \\
1 \text { 月発注回数は } 8 \text { 回以内 }\end{array}$ \\
\hline 救急品目 & 救急管理 & 1 回使用量を薬品倉庫に常備 \\
\hline 希用品目 & $\begin{array}{l}\text { デッドストッ } \\
\text { ク対策 }\end{array}$ & $\begin{array}{l}\text { 使用頻度が少なく、請求点を定めてむ意 } \\
\text { 味の無い品目を希用薬とした。具体的に } \\
\text { は } 3 \text { カ月間の購入がゼロの品目。計算上 } \\
\text { の請求点が、包装単位の10分の } 1 \text { 以下の } \\
\text { 品目。及び、バラ錠。 }\end{array}$ \\
\hline 倉庫在庫品目 & $\begin{array}{l}\text { 問屋の配送お } \\
\text { よび調剂室の } \\
\text { 在庫場所スぺ } \\
\text { ースの考虑 }\end{array}$ & $\begin{array}{l}\text { 一部の輸液等、大型の品目は倉庫在庫を } \\
\text { 持つ。バーコードによる請求ではなく、 } \\
\text { 伝票による請求とした。 }\end{array}$ \\
\hline 特別管理品目 & 品切れ対策 & $\begin{array}{l}\text { 請求点をかさ上げする品目使用量に波の } \\
\text { ある品目で、1目の使用量が、計算上の } \\
4 \text { 日分の平均使用量をオーバーする可能 } \\
\text { 性のある品目。 }\end{array}$ \\
\hline 高価薬 & 経済的管理 & $\begin{array}{l}\text { A B C 分析のA品目に相当する。年度毎 } \\
\text { に、消費金額より定め、全消費の } 70 \text { 品。 } \\
80 \% \text { 古める登注回数を } 8 \\
\text { 請求点を } 4 \text { 日に定め、1 } \\
\text { 回を標準とする。 }\end{array}$ \\
\hline
\end{tabular}

表 4. 在庫管理要因の分布

期間 平成 4 年 9 月一同年 11 月

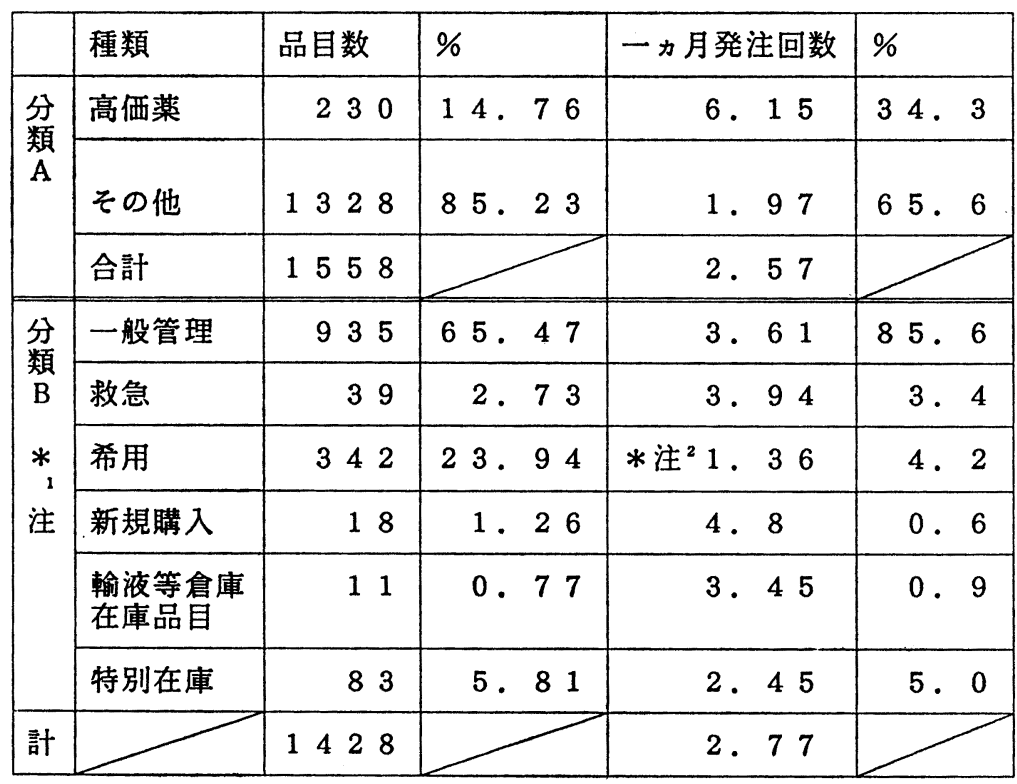

* 注1 分類 B ではバラ錠（錠剂分包用に購入、便宜上希用薬としている）を 省いた。

*注 2 購入数ゼロの品目は省いた。 
表 5. 新, 旧システムの業務量の比較

システム導入前（平成 3 年 9 月一同年 11 月）と導入後（平成 4 年 9 月一 同年 10 月）の一月平均の業務量の比較

（）は平均柴務の延べ時間：人数 $\times$ 所要時間

\begin{tabular}{|c|c|c|c|}
\hline 業務内容 & 旧システム & 新システム & 備考 \\
\hline 定期納品数 & $1628 \quad(24)$ & $3362(48)$ & $\begin{array}{l}\text { 新システムは、 } \\
\text { 入庫せずに払い } \\
\text { 出す。 }\end{array}$ \\
\hline 臨時納品数 & 303 & 32 & $\begin{array}{l}\text { 新システムは平 } \\
\text { 成 } 5 \text { 年 } 5 \text { 月のデ } \\
\text {-タ。 }\end{array}$ \\
\hline 各室受入数 & $4223 \quad(33)$ & $3484 \quad(7)$ & $\begin{array}{l}\text { 新システムは輸 } \\
\text { 液の庫出に要す } \\
\text { 時間。輸液外 } \\
\text { は定期納品の時 } \\
\text { 間に含まれる。 } \\
\text { 旧シテムは倉 } \\
\text { 庫在庫からの軽 } \\
\text { 出時間。 }\end{array}$ \\
\hline 入力数 & $6154 \quad(33)$ & $\begin{array}{c}155+\text { 未納品目の } \\
\text { 後入力 } \\
\text { (5) }\end{array}$ & $\begin{array}{l}\text { 未納品目は一旦 } \\
\text { 平均 } 3-5 \text { 品目 } \\
155 \text { は血液、放 } \\
\text { 射性医薬品等の } \\
\text { 入力。 }\end{array}$ \\
\hline
\end{tabular}

表 6. 在庫管理パラメーターの更新のための統計資料例

EX.

担当 注射薬

1 月 9 回以上の購入品目

参考 計算上の数值

\begin{tabular}{|c|c|c|c|c|c|c|c|c|c|c|c|c|}
\hline 1807 & 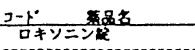 & & $\frac{\text { 包薄 }}{1.0001}$ & $\frac{1597}{35.333}$ & 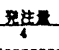 & 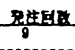 & $\frac{\text { 小国 }}{10.000}$ & $\frac{k 101}{8.000}$ & 1) $18 x$ & 23 & 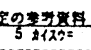 & 7 \\
\hline 2212 & ソランタールれ & 6 & 100) & 1.887 & 2 & 10 & 100 & 2008 & 2) & $23=$ & $3 t(x)=$ & 7 \\
\hline 1751 & $v=x-x+2$ & 1 & $1,000)$ & 8.887 & 1 & 9 & 3.000 & 2,0001 & 5) & $23=$ & $2 *\{1\}=$ & 5 \\
\hline 2210 & カルスロントは 20 & 1 & 100) & 2.900 & 3 & 10 & 700 & $r 490$ & 3) & $23=$ & $t *(x)=$ & 8 \\
\hline 2030 & ハイロテンシン部 $5 \mathrm{mg}$ & 1 & 100) & 2,800 & 3 & 10 & 800 & 3000 & 2) & $23=$ & $1 * 12\}=$ & 7 \\
\hline 1987 & メパロチン & 1 & $1,000)$ & 20.687 & 2 & 11 & 5,000 & 3,0001 & 3) & $2 y=$ & $3 t(x)=$ & 7 \\
\hline 2288 & リホハくス政 5 & 1 & $100)$ & 800 & 1 & 8 & 100 & of & 0) & $2 y=$ & $2 t|x\rangle=$ & 5 \\
\hline 2207 & オメフフールは & 1 & $100)$ & 933 & 1 & 10 & 200 & 1006 & 2) & $2 y=$ & 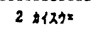 & 5 \\
\hline 680 & シスコン & 1 & $1,000)$ & 8,687 & 1 & 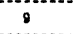 & 3,000 & 2,0001 & 5) & $23=$ & $2 x \mid x\} x$ & 5 \\
\hline 1277 & フロスタール & 1 & 100) & 1.867 & 2 & 9 & 600 & 4001 & 8) & $20=$ & $3 t\langle(\lambda)=$ & 8 \\
\hline 822 & セルニルトン䓍 & 1 & $500)$ & 28,000 & $B$ & $\theta$ & 7,000 & 4.0001 & 3) & $x \rightarrow=$ & $7 \sharp\langle\lambda\}=$ & 8 \\
\hline 1847 & ロカルトロールカフセル & 1 & $100)$ & 2,033 & 2 & 15 & 700 & 5008 & 4) & $x \rightarrow=$ & $4 t\{z\}=$ & 8 \\
\hline 1652 & クリニミール & 1 & 20) & 207 & 1 & 11 & 20 & or & 0) & $29=$ & $2 D(x\}=$ & 6 \\
\hline 2250 & ヘハンED & 1 & 14) & 487 & 4 & 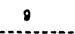 & 188 & 1126 & 6) & $x \rightarrow=$ & $S t\{x\}=$ & 7 \\
\hline 714 & クレスチン末 & 1 & 105) & 5,850 & 5 & 12 & 1,525 & 1,0001 & 4) & $23=$ & $7 \pm\{\lambda\rangle=$ & 8 \\
\hline 1654 & スーエフティカプル & 6 & 120) & 16,800 & 15 & 10 & 5,800 & 1.0001 & 5) & $x y=$ & $18 \pm\{23=$ & 8 \\
\hline 2251 & セフソンカフセル & 1 & $500)$ & 4.833 & 1 & 10 & 1.100 & 8001 & 3) & $x \rightarrow=$ & $21(x)=$ & 5 \\
\hline
\end{tabular}




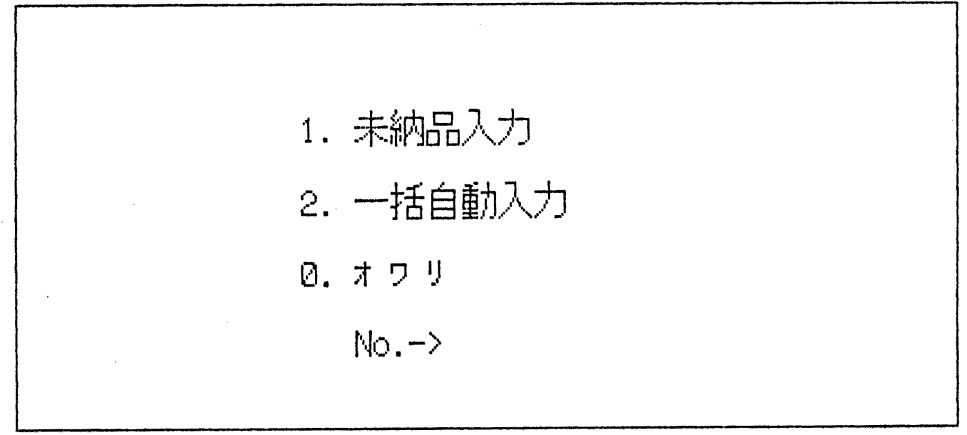

困 11. 出納処理プログラムメニュ一画面

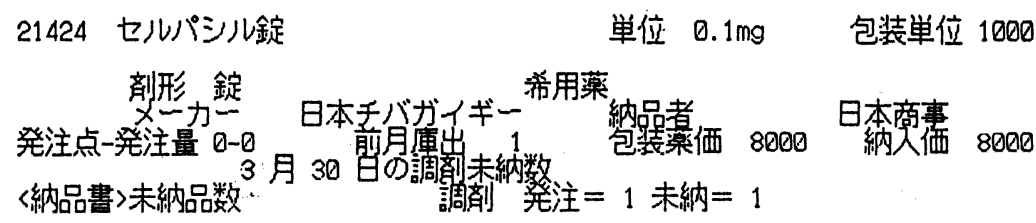

未納数を入力して下さい。中止なら* 訂正のため一の入力可

図 12. 未納品入力画面

特殊要因の設定品目

○希用薬

\section{統計資料の作成}

最近の 3 カ月のデーターを基に下記の出納資料 を請求担当別に作成する. 表 6 に統計資料の例を 示す.

\section{6. 出納処理}

納品後コンピューターへの記録は, 未納品目を キーボードから入力し, 未納品以外は, 納品とし て自動的に記録される（図11）.

納品後, 未納数（通常 5 点以内）をキーボード から入力する（図12）.
入力後, 未納数を除いた出納入力を自動一括処 理（メニューの一括入力を選択）する. 即ち, 発 注の記録がそのまま納品, 庫出のフィルードに納 品, 庫出の記録としてコピーされ, 発注の記録は クリアーされる. 処理後, 未納品目一覧表をプリ ントアウトし確認する.

後日 (一両日中), 未納品が納品されればキーボ 一ドから入力する.

以上のシステムの追加により, コンピューター へのキーボードからの入力が殆どなくなった。 ま た, 発注書と翌日納品予定品目の一覧表, 納品時 の検収および，出納入打は，図13に示したよう

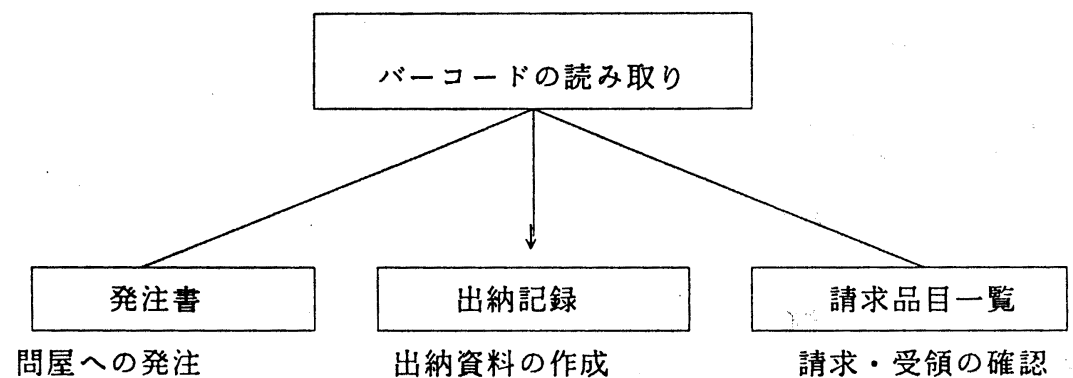

問屋への発注

出納資料の作成

請求・受領の確認

図 13. バーコード記録と在庫管理業務の関係 
に，同じ発生源（バーュードの読み取り）であ り, システム的に人為的な操作が排除できた。

その他の出納資料の作成等の業務は従来通りで ある。

\section{7. 結果}

きめの細かい, 在庫管理要因の設定と管理によ り, 以下の改善がみられた。

A. 統計的な請求点の設定と毎日納品により, 品切れが殆ど生じなくなり, 問屋への急配依頼が 殆どなくなった。 また，平成 4 年 2 月の実施か ら, 現在（平成 5 年 1 月）まで, 治療上影響を与 えるような品切れはなかった。

B. バーュードの利用によりコンピューターヘ のキーボードからの入力が激減し, 事務量が減っ た. 旧方式では, 納品伝票, 庫出伝票をキーボー ドから入力していたが, 納品＝庫出としてコンピ ニーター内で自動変換入力する事により，キーボ ード入力が半減し，バーュード入力二納品とする ことにより，キーボードからの入力は殆どなくな った.

C. 倉庫に在庫する品目が, 救急薬, 一部の輸 液以外, 殆どなくなり，入出庫に要していた業務 が激減した。

D. 業務の合理化により，服薬指導等病棟活動 等に時間を当てることができた。

当院の在庫管理のコンピューターシステムは 10 年来, パーソナルコンピューターのレベルで, 種 々の要請に応じて，改良を加えてきたシステムで ある.

今回はこのシステムにバーコードシステムを組 み込み, 業務の合理化を図り, 所期の目的を達し た。

\section{おわりに}

今や，薬品の在庫管理にコンピューターシステ ムを使用するのは，当たり前のようになってい る. システムも大手メーカーが参入した，大がか りなものになりつつある.

しかし，基本的な考え方は，流動的な薬品の使 用量に対処するため, 薬品の特性 (緊急性, 経済
性，使用量）を十分配虑し，しかも，誰にでもで きる簡単な運用方式により維持できるシステムで なければならないと思う。

当薬剤部のシステムの中心は, バーュードシス テムでも，自動発注でもなく，定期的に行ら在庫 管理パラメーターの検討だと思っている．それに よって適切な在庫管理が維持できると考える。

また，今回，注意したのは，システムの基準に 合わない例外品目の対処である，例えば，倉庫に 在庫しないという基準を定めたとしても，必ず例 外が生じる. 例外はやがて, システムの歪になる だろう．要は，例外をいかに把握し，管理するか ということである，その点についても，在庫管理 要因の中に含め十分に検討した，現在さらに，在 庫管理要因の検討にコンピューターによる自動解 析を考えている.

自作のプログラムによる業務システムは，いろ いろと融通が効くといら利点の反面，その人間が いなければ不都合が生じるといら欠点がある。い ずれ, 当院の薬品在庫管理も, トータルシステム の中に組みこまれるか, パックシステムに移行す るだろら．そうなっても，基本的な考方方が，十 分に反映したシステムでなければならないと思 亏.

現在のコンピューターシステムは，人間の要望 を無尽藏に受け入れてくれる魔法のBOXではな い.実際の仕事にかかわる人間がきっちりとした 考方を示さなければ，いたずらにシステムに振 り回されることになるだろう.

\section{引用文 献}

1）中西弘和, 山本雅代, 伊藤幸子, 新宮とし子, 花 井永実, 須藤和勇, 福中 実, 坂東 進, 医薬シ ヤーナル, 26, 1905 (1990).

2）矢島治子, 青野恭子, 鈴木千春, 医薬 ジャ一ナ ル, 26, 1439 (1990).

3）青野恭子, 医薬シャャーナル，26，1661 (1990).

4) 後藤伸之, 岩井紀美江, 油尾真弓, 大久保和代, 杉山正敏, 岡村研太郎, 出倉義昭, 牧野忠志, 高 島三男, 中島周二, JJSHP, 27(3) (1991).

5) 深井克彦, 田畑耕一, 月刊薬事, 32(2) (1990). 